\title{
KERAGAAN PERTUMBUHAN IKAN TAMBAKAN (Helostoma temminckii Cuvier, 1829) DENGAN KEPADATAN BERBEDA
}

\author{
Otong Zenal Arifin\#, Wahyulia Cahyanti, dan Vitas Atmadi Prakoso
}

Balai Riset Perikanan Budidaya Air Tawar dan Penyuluhan Perikanan

Jl. Sempur No. 1, Bogor 16129

(Naskah diterima: 4 Februari 2019; Revisi final: 6 Maret 2019; Disetujui publikasi: 8 Maret 2019)

\begin{abstract}
ABSTRAK
Padat tebar merupakan salah satu faktor yang berpengaruh terhadap keragaan pertumbuhan dalam budidaya ikan. Penelitian ini dilakukan untuk mengetahui kepadatan optimum untuk pertumbuhan ikan tambakan. Penelitian ini dilakukan di Instalasi Riset Plasma Nutfah Perikanan Air Tawar, Cijeruk, Balai Riset Perikanan Budidaya Air Tawar dan Penyuluhan Perikanan (BRPBATPP), Bogor. Ikan tambakan generasi ke-2 dengan panjang total $2,10 \pm 0,18 \mathrm{~cm}$ dan bobot 4,83 $\pm 0,17 \mathrm{~g}$ yang diperoleh melalui program domestikasi dipelihara di kolam bak beton yang diberi sekat (ukuran $3 \mathrm{~m} \times 3,5 \mathrm{~m} \times 1 \mathrm{~m}$ ). Pakan komersial berupa pelet terapung (protein 39\%41\% lemak 5\% diberikan sebanyak 3\% per hari dari biomassa dengan frekuensi pemberian sebanyak tiga kali. Perlakuan kepadatan yang dilakukan pada penelitian adalah 25, 50, dan 75 ekor/m² dengan tiga ulangan. Pengambilan data dilakukan setiap 30 hari sebanyak 30 ekor dari setiap ulangan selama 150 hari masa pemeliharaan terhadap panjang, bobot, kelangsungan hidup, biomassa, dan rasio konversi pakan. Pengukuran kualitas air juga dilakukan sebagai data pendukung. Hasil penelitian menunjukkan bahwa pertumbuhan panjang baku, panjang total, bobot, dan sintasan tertinggi diperoleh pada kepadatan 25 ekor/m².
\end{abstract}

KATA KUNCl: Helostoma; tambakan; kepadatan; pertumbuhan; sintasan

ABSTRACT: Growth performance of kissing gourami (Helostoma temminckii Cuvier, 1829) at different stocking densities. By: Otong Zenal Arifin, Wahyulia Cahyanti, and Vitas Atmadi Prakoso

Stocking density is one of the influencing growth performance indicators in aquaculture. This study was conducted to determine the optimum stocking density in optimizing the growth rate of kissing gourami. The study was carried out at the Research Station for Freshwater Fisheries Germplasm, Cijeruk, RIFAFE Bogor. A second generation of kissing gourami with total length of $2.10 \pm 0.18 \mathrm{~cm}$ and body weight of $4.83 \pm 0.17 \mathrm{~g}$ produced from a domestication program were reared in separated-nets concrete ponds (pond division: $3 \mathrm{~m} \times 3,5 \mathrm{~m} \times 1 \mathrm{~m}$ ) and fed using commercial floating pellets (protein: $39 \% 41 \%$ lipid: $5 \%$. Feed was given 3\% of biomass per day with a feeding frequency of three times per day. Stocking density treatments in this study were 25,50 , and $75 \mathrm{fish} / \mathrm{m}^{2}$ with three replications. Data collection was conducted every 30 days from 30 fish in each replicate during 150 days of rearing period on growth parameters including length, weight, survival rate, biomass, and feed conversion ratio. Water quality measurement was also conducted as supplementary data. The results showed that the highest values on standard length gain, absolute length gain, weight gain, and survival rate were found in the fish population with a stocking density of $25 \mathrm{fish} / \mathrm{m}^{2}$.

KEYWORDS: Helostoma; kissing gourami; stocking density; growth; survival

\section{PENDAHULUAN}

Ikan tambakan (Helostoma temminckii Cuvier, 1829) merupakan salah satu jenis ikan air tawar bernilai ekonomis tinggi dan berpotensi untuk dikembangkan sebagai ikan budidaya (Gustiano et al., 2015). Sebagai

\# Korespondensi: Balai Riset Perikanan Budidaya Air Tawar dan Penyuluhan Perikanan. Jl. Sempur No. 1, Bogor 16129, Indonesia Tel.: + 622518313200

E-mail: zenalarifin@gmail.com salah satu sumber daya genetik ikan liar yang sudah dapat diadaptasikan, produksi ikan tambakan masih sangat bergantung pada hasil tangkapan alam. Sementara itu, pemeliharaan dalam wadah budidaya terkontrol masih jarang dilakukan (Gustiano et al., 2015). Menurut Weber $\&$ de Beaufort (1922), ikan tambakan terdapat di wilayah Asia Tenggara seperti Thailand, Semenanjung Malaysia, dan Indonesia (Sumatera, Jawa, dan Kalimantan). 
Salah satu tahapan budidaya pada ikan tambakan yang masih belum banyak diketahui adalah pendederan dan pembesaran. Pendederan perlu dilakukan untuk mendapatkan benih yang baik kualitasnya sebelum ditebar di kolam pembesaran, yang bertujuan untuk mengurangi tingkat kematian dan mendapatkan benih yang seragam.

Salah satu persoalan penting dalam tahap pembesaran adalah padat tebar yang sangat berkaitan dengan optimalnya tingkat sintasan, pertumbuhan, dan kualitas ikan yang akan menjadi faktor pembatas biaya produksi. Penelitian tentang padat tebar ikan tambakan telah dilakukan oleh Cheah et al. (1985) dan Joko et al. (2013). Namun kedua penelitian tersebut dilakukan terhadap larva, sehingga dirasa perlu untuk mengetahui bagaimana padat tebar akan berpengaruh pada fase pembesaran.

Berdasarkan informasi tersebut, penelitian ini dilakukan dengan tujuan untuk mengetahui pertumbuhan, sintasan, dan produktivitas ikan tambakan dengan perlakuan padat tebar yang berbeda.

\section{BAHAN DAN METODE}

Ikan uji yang digunakan yaitu ikan tambakan generasi ke-2 dengan panjang total 2,10 $\pm 0,18 \mathrm{~cm}$ dan bobot 4,83 $\pm 0,17 \mathrm{~g}$ hasil program domestikasi. Pemeliharaan dilakukan di kolam bak beton yang diberi sekat ukuran $3 \mathrm{~m} \times$ 3,5 m x $1 \mathrm{~m}$. Pakan komersial berupa pelet terapung dengan protein $39 \% 41 \%$ dan lemak 5\% diberikan sebesar 3\% biomassa per hari dengan frekuensi tiga kali. Perlakuan padat penebaran adalah 25, 50, dan 75 ekor $/ \mathrm{m}^{2}$ dengan tiga ulangan. Pengambilan data ikan dilakukan setiap 30 hari sebanyak 30 ekor dari total ikan perlakuan untuk setiap ulangan selama 150 hari masa pemeliharaan. Parameter yang diamati adalah sintasan, pertumbuhan mutlak, laju pertumbuhan spesifik, dan rasio konversi pakan yang dihitung menurut Effendie (2002), beberapa rumus disajikan sebagai berikut:

Laju pertumbuhan spesifik panjang

$$
\operatorname{SGR}(\%)=\left(\frac{\ln \mathrm{Lt}-\ln \mathrm{Lo}}{\mathrm{t}}\right) \times 100
$$

di mana:

SGR = laju pertumbuhan spesifik

Lt = panjang akhir rata-rata ikan hari ke-t (cm/ekor)

Lo $=$ panjang awal rata-rata ikan (cm/ekor)

In = logaritma natural dengan basis e (konstanta Euler)

$\mathrm{t}=$ hari

Laju pertumbuhan spesifik bobot

$$
\operatorname{SGR}(\%)=\left(\frac{\ln W \mathrm{t}-\ln W_{0}}{\mathrm{t}}\right) \times 100
$$

di mana:

$\mathrm{SGR}=$ laju pertumbuhan spesifik (specific growth rate)

$W t=$ bobot akhir rata-rata ikan hari ke-t (g/ekor)

$W_{0}=$ bobot awal rata-rata ikan (g/ekor)

In = logaritma natural dengan basis e (konstanta Euler)

$\mathrm{t}=$ hari

Rasio konversi pakan

$$
\mathrm{FCR}=\left(\frac{\mathrm{F}}{\mathrm{Bt}-\mathrm{Bo}}\right)
$$

di mana:

$\mathrm{FCR}=$ rasio konversi pakan (feed conversion ratio)

$\mathrm{F}=$ jumlah pakan yang dikonsumsi selama pemeliharaan $(\mathrm{kg})$

$\mathrm{Bt}=$ biomassa akhir $(\mathrm{kg})$

Bo $=$ biomassa awal $(\mathrm{kg})$

\section{HASIL DAN BAHASAN}

Pertumbuhan ikan tambakan pada fase pembesaran selama 150 hari pemeliharaan memperlihatkan bahwa perlakuan kepadatan 25 ekor $/ \mathrm{m}^{2}$ menunjukkan pertumbuhan mutlak panjang standar dan laju pertumbuhan spesifik yang lebih tinggi dan tidak berbeda nyata $(P>0,05)$ dengan kepadatan 50 ekor/ $\mathrm{m}^{2}$ namun berbeda nyata $(P<0,05)$ dengan perlakuan kepadatan 75 ekor $/ \mathrm{m}^{2}$ (Tabel 1).

Pertumbuhan bobot mutlak dan laju pertumbuhan spesifik bobot menunjukkan perlakuan kepadatan 25 ekor $/ \mathrm{m}^{2}$ menghasilkan nilai tertinggi dan berbeda nyata $(P<0,05)$ dengan perlakuan kepadatan 75 ekor $/ \mathrm{m}^{2}$, namun tidak berbeda nyata $(P>0,05)$ dengan perlakuan kepadatan 50 ekor $/ \mathrm{m}^{2}$ (Tabel 2).

Biomassa akhir tertinggi diperoleh pada kepadatan 50 dan 75 ekor $/ \mathrm{m}^{2}$. Sementara itu, sintasan tertinggi diperoleh pada kepadatan 25 ekor $/ \mathrm{m}^{2}$ dan berbeda nyata $(P<0,05)$ dengan kepadatan lainnya. Nilai rasio konversi pakan pada masing-masing perlakuan kepadatan tidak berbeda nyata $(P>0,05)$ (Tabel 3$)$.

Data sintasan tertinggi diperoleh pada kepadatan 25 ekor $/ \mathrm{m}^{2}$ dan berbeda nyata $(P<0,05)$ dengan kepadatan lainnya. Sementara itu, penelitian perbedaan kepadatan larva oleh Joko et al. (2013) memperoleh hasil yang tidak berbeda nyata antar perlakuan. Hal tersebut diduga karena penelitian ini menggunakan ikan berukuran benih sehingga kompetisi ruang gerak yang terjadi lebih besar bila dibandingkan dengan larva. Yulianti et al. (2003) menyatakan semakin sempit ruang gerak menyebabkan terjadinya persaingan untuk bertahan hidup, sehingga berpotensi menjadikan ikan stres dan mengalami kematian.

Nilai rasio konversi pakan pada masing-masing perlakuan kepadatan tidak berbeda nyata $(P>0,05)$ dengan nilai yang cukup baik yaitu di bawah dua 
Tabel 1. Panjang standar, pertumbuhan panjang mutlak dan laju pertumbuhan spesifik pada pembesaran ikan tambakan selama 150 hari dengan padat tebar berbeda

Table 1. Standard length, absolute length gain, and specific growth rate of kissing gourami reared for 150 days at different stocking densities

\begin{tabular}{|c|c|c|c|c|}
\hline \multirow{2}{*}{$\begin{array}{c}\text { Padat tebar } \\
\left.\text { (ekor } / \mathrm{m}^{2}\right) \\
\text { Stocking density } \\
\left(\text { fish } / \mathrm{m}^{2}\right)\end{array}$} & \multicolumn{2}{|c|}{$\begin{array}{c}\text { Panjang standar } \\
\text { Standard length }(\mathbf{c m})\end{array}$} & \multirow{2}{*}{$\begin{array}{l}\text { Pertumbuhan mutlak } \\
\text { panjang standar } \\
\text { Standard length gain } \\
\text { (cm) }\end{array}$} & \multirow{2}{*}{$\begin{array}{l}\text { Laju pertumbuhan } \\
\text { spesifik panjang (\%hari) } \\
\text { Specific growth rate } \\
\text { of length (\%day) }\end{array}$} \\
\hline & $\begin{array}{l}\text { Awal } \\
\text { Initial }\end{array}$ & $\begin{array}{l}\text { Akhir } \\
\text { Final }\end{array}$ & & \\
\hline 25 & $3.52 \pm 0.255$ & $8.15 \pm 0.206^{b}$ & $4.64 \pm 0.205^{b}$ & $0.56 \pm 0.041^{b}$ \\
\hline 50 & $3.76 \pm 0.179$ & $8.02 \pm 0.377^{\mathrm{ab}}$ & $4.26 \pm 0.397^{\mathrm{ab}}$ & $0.50 \pm 0.042^{\mathrm{ab}}$ \\
\hline 75 & $3.53 \pm 0.059$ & $7.29 \pm 0.421^{a}$ & $3.76 \pm 0.374^{\mathrm{a}}$ & $0.48 \pm 0.031^{a}$ \\
\hline
\end{tabular}

Keterangan: Notasi huruf yang sama menunjukkan tidak berbeda nyata $(P>0,05)$

Note: $\quad$ The same letter notation shows no significant difference $(P>0.05)$

(Tabel 4). Hal ini diduga karena ikan yang digunakan merupakan generasi pertama hasil domestikasi, artinya ikan tambakan telah beradaptasi terhadap penggunaan pakan buatan berupa pelet komersil. Hasil yang bertolak belakang diperoleh Augusta (2016) di mana nilai konversi pakan yang diperoleh tergolong tinggi $(3,3)$, sebab ikan yang digunakan adalah ikan awal domestikasi. Ikan dalam masa awal domestikasi memerlukan waktu untuk beradaptasi terhadap kondisi lingkungan kolam yang membuat ikan jadi stres, sakit, bahkan sampai mengalami kematian.

Pada penelitian ini, tidak ditemukan adanya perbedaan yang nyata pada semua parameter kualitas air yang diukur untuk masing-masing perlakuan kepadatan $(P>0,05)$ (Tabel 4$)$.

Dari hasil pengamatan pertumbuhan panjang dan bobot, serta pertumbuhan spesifik diperoleh hasil tertinggi pada perlakuan dengan kepadatan terendah yaitu $25 \mathrm{ekor} / \mathrm{m}^{2}$. Hal tersebut sesuai dengan Joko et al. (2013) yang melakukan penelitian serupa dengan kepadatan berbeda. Lebih tingginya pertumbuhan panjang dan bobot mutlak pada padat tebar rendah (6 dan 8 ekor/L) diduga disebabkan lebih luasnya ruang gerak bagi larva ikan tambakan sehingga mengurangi kompetisi untuk memanfaatkan ruang gerak. Sempitnya ruang gerak mengakibatkan ikan lebih banyak membutuhkan energi untuk mempertahankan aktivitas tubuh. Menurut Effendie (2002), keadaan lingkungan merupakan faktor dari luar yang dapat memengaruhi pertumbuhan ikan, sedangkan faktor dari dalam yang memengaruhi pertumbuhan ikan yaitu keturunan, jenis kelamin, umur, parasit, dan penyakit.

Menurut National Research Council (1993), sebelum digunakan untuk pertumbuhan, energi terlebih dahulu digunakan untuk memenuhi seluruh aktivitas dan pemeliharaan tubuh melalui metabolisme. Laju pertumbuhan adalah karakteristik setiap spesies dan termasuk ke dalam tahap perkembangan.

Tabel 2. Bobot, pertumbuhan mutlak, dan laju pertumbuhan spesifik pada pembesaran ikan tambakan selama 150 hari padat tebar berbeda

Table 2. Weight, absolute weight gain, and specific growth rate of kissing gourami reared for 150 days at different stocking densities

\begin{tabular}{|c|c|c|c|c|}
\hline \multirow{2}{*}{$\begin{array}{c}\text { Padat tebar } \\
\left(\text { ekor } / \mathrm{m}^{2}\right) \\
\text { Stocking density } \\
\left(\text { fish } / \mathrm{m}^{2}\right)\end{array}$} & \multicolumn{2}{|c|}{ Bobot (Weight) (g) } & \multirow{2}{*}{$\begin{array}{l}\text { Pertumbuhan } \\
\text { bobot } \\
\text { Weight gain } \\
\text { (g) }\end{array}$} & \multirow{2}{*}{$\begin{array}{l}\text { Pertumbuhan spesifik } \\
\text { bobot (\%hari) } \\
\text { Specific growth rate } \\
\text { of weight (\%day) }\end{array}$} \\
\hline & $\begin{array}{l}\text { Awal } \\
\text { Initial }\end{array}$ & $\begin{array}{l}\text { Akhir } \\
\text { Final }\end{array}$ & & \\
\hline 25 & $1.91 \pm 0.357$ & $20.16 \pm 0.645^{b}$ & $18.25 \pm 0.613^{b}$ & $1.58 \pm 0.127^{b}$ \\
\hline 50 & $2.27 \pm 0.110$ & $19.76 \pm 1.319^{b}$ & $17.50 \pm 1.313^{b}$ & $1.44 \pm 0.051^{b}$ \\
\hline 75 & $2.13 \pm 0.095$ & $13.76 \pm 3.014^{\mathrm{a}}$ & $11.63 \pm 2.918^{\mathrm{a}}$ & $1.23 \pm 0.120^{a}$ \\
\hline
\end{tabular}

Keterangan: notasi huruf yang sama menunjukkan tidak berbeda nyata $(P>0,05)$

Note: $\quad$ The same letter notation shows no significant difference $(P>0.05)$ 
Tabel 3. Biomassa, sintasan, dan rasio konversi pakan ikan tambakan selama pemeliharaan 150 hari

Table 3. Biomass, survival rate, and feed conversion ratio of kissing gourami reared for 150 days

\begin{tabular}{|c|c|c|c|c|}
\hline \multirow{2}{*}{$\begin{array}{c}\text { Padat tebar } \\
\text { (ekor } / \mathrm{m}^{2} \text { ) } \\
\text { Stocking density } \\
\left(\text { fish } / \mathrm{m}^{2} \text { ) }\right.\end{array}$} & \multicolumn{2}{|c|}{ Biomassa (Biomass) (kg) } & \multirow{2}{*}{$\begin{array}{c}\text { Sintasan } \\
\text { Survival rate } \\
(\%)\end{array}$} & \multirow{2}{*}{$\begin{array}{l}\text { Rasio konversi pakan } \\
\text { Feed conversion ratio }\end{array}$} \\
\hline & $\begin{array}{l}\text { Awal } \\
\text { Initial }\end{array}$ & $\begin{array}{l}\text { Akhir } \\
\text { Final }\end{array}$ & & \\
\hline 25 & $0.5 \pm 0.09$ & $4.2 \pm 0.50^{\mathrm{a}}$ & $83.1 \pm 7.43^{b}$ & $1.85 \pm 0.045^{\mathrm{a}}$ \\
\hline 50 & $1.1 \pm 0.06$ & $7.3 \pm 0.55^{b}$ & $73.5 \pm 2.40^{b}$ & $1.78 \pm 0.036^{\mathrm{a}}$ \\
\hline 75 & $1.6 \pm 0.07$ & $7.0 \pm 1.47^{b}$ & $68.0 \pm 1.80^{\mathrm{a}}$ & $1.79 \pm 0.042^{\mathrm{a}}$ \\
\hline
\end{tabular}

Keterangan: Notasi huruf yang sama menunjukkan tidak berbeda nyata $(P>0,05)$

Note: $\quad$ The same letter notation shows no significant difference $(P>0.05)$

Tabel 4. Kualitas air media pemeliharaan ikan tambakan (Helostoma temminckii) dengan perlakuan padat tebar berbeda selama 150 hari masa pemeliharaan

Table 4. Water quality in rearing media of kissing gourami reared for 150 days at different stocking densities

\begin{tabular}{|c|c|c|c|}
\hline \multirow[t]{2}{*}{ Parameter (Parameters ) } & \multicolumn{3}{|c|}{$\begin{array}{l}\text { Padat tebar (ekor } / \mathrm{m}^{2} \text { ) } \\
\text { Stocking density (fish } / \mathrm{m}^{2} \text { ) }\end{array}$} \\
\hline & 25 & 50 & 75 \\
\hline Suhu (Temperature) $\left({ }^{\circ} \mathrm{C}\right)$ & $25.33 \pm 1.528$ & $25.67 \pm 1.528$ & $25.83 \pm 1.607$ \\
\hline $\mathrm{pH}$ & $6.59 \pm 0.827$ & $6.43 \pm 1.266$ & $6.50 \pm 1.513$ \\
\hline Oksigen terlarut (Dissolved oxygen ) (mg/L) & $8.00 \pm 2.646$ & $7.67 \pm 2.255$ & $7.83 \pm 2.843$ \\
\hline Konduktivitas (Conductivity) & $97.33 \pm 3.786$ & $100.00 \pm 6.000$ & $101.33 \pm 8.505$ \\
\hline TDS (mg/L) & $49.33 \pm 3.055$ & $49.67 \pm 4.726$ & $50.00 \pm 4.583$ \\
\hline Turbiditas (Turbidity) (NTU) & $20.50 \pm 13.919$ & $20.83 \pm 14.785$ & $21.17 \pm 15.267$ \\
\hline $\mathrm{NH}_{3}-\mathrm{N}(\mathrm{mg} / \mathrm{L})$ & $0.41 \pm 0.359$ & $0.42 \pm 0.391$ & $0.43 \pm 0.410$ \\
\hline $\mathrm{NO}_{2}-\mathrm{N}(\mathrm{mg} / \mathrm{L})$ & $0.03 \pm 0.025$ & $0.03 \pm 0.027$ & $0.03 \pm 0.029$ \\
\hline $\mathrm{NO}_{3}-\mathrm{N}(\mathrm{mg} / \mathrm{L})$ & $0.30 \pm 0.300$ & $0.30 \pm 0.300$ & $0.33 \pm 0.351$ \\
\hline
\end{tabular}

Pertumbuhan ikan bergantung pada beberapa faktor, yaitu jenis ikan, sifat genetik dan kemampuan memanfaatkan pakan, ketahanan terhadap penyakit, serta didukung oleh faktor lingkungan seperti kualitas air. Rainboth (1996) mengemukakan bahwa ikan tambakan merupakan salah satu ikan Anabantidae dengan pertumbuhannya lambat.

Effendie (2002) mengemukakan bahwa keadaan lingkungan merupakan faktor dari luar yang dapat memengaruhi pertumbuhan ikan, sedangkan faktor dari dalam yang memengaruhi pertumbuhan ikan yaitu keturunan, jenis kelamin, umur, serta parasit dan penyakit. Hasil pertumbuhan dan sintasan terbaik penelitian ini diperoleh pada padat penebaran rendah. Hal yang serupa diperoleh pada ikan lalawak (Barbonymus balleroides) (Arifin et al., 2017a). Padat tebar merupakan salah satu faktor luar yang berpengaruh terhadap keragaan pertumbuhan dalam pemeliharaan ikan. Luasan media pemeliharaan merupakan faktor pembatas dalam pertumbuhan ikan yang dipelihara dan merupakan faktor penting dalam budidaya ikan.

Sintasan ikan tambakan tertinggi juga diperoleh pada pemeliharaaan ikan dengan kepadatan terendah. Kecilnya tingkat kematian benih ikan tambakan dikarenakan kondisi lingkungan yang ideal dalam pemeliharaannya. Menurut Hepher \& Pruginin (1981), parameter pemeliharaan ikan pada kepadatan tinggi adalah hasil yang maksimal. Pada pemeliharaan ikan secara intensif, peningkatan padat tebar biasa dilakukan untuk mengetahui hasil maksimal yang dapat dicapai. Jika hasil yang didapat belum mencapai 
maksimal atau belum menurun, maka masih dimungkinkan untuk meningkatkan padat tebar ikan walaupun pertumbuhannya cenderung menurun.

Berdasarkan hasil uji ketahanan terhadap suhu, Arifin et al. (2017b) mengemukakan bahwa ikan tambakan mampu bertahan hidup dan beraktivitas secara normal pada suhu $20^{\circ} \mathrm{C}$. Akan tetapi, suhu $15^{\circ} \mathrm{C}$ atau lebih rendah bersifat letal bagi ikan tambakan. Sementara itu, pada suhu tinggi, ikan tambakan mampu hidup pada suhu $35^{\circ} \mathrm{C}$ dengan sintasan $100 \%$ namun mengalami kematian pada suhu $40^{\circ} \mathrm{C}$ dengan jumlah kematian total pada menit ke-5.

Randall (1982) mengemukakan bahwa tingkat oksigen terlarut letal bagi ikan berbeda-beda, tergantung spesies dan tingkat adaptasinya. Pada tingkat akut, kekurangan oksigen akan memengaruhi pertumbuhan dan sintasan ikan (Smith \& Able, 2003). Hasil uji tingkat oksigen letal yang dilakukan Arifin et al. (2017b) menunjukkan bahwa ikan tambakan hanya bertahan selama 30 sampai 38 menit dengan adanya penurunan tingkat oksigen terlarut yang drastis di dalam wadah pemeliharaan secara tertutup dan mulai terjadi kematian pada saat oksigen terlarut menjadi $1,8 \mathrm{mg} / \mathrm{L}$.

\section{KESIMPULAN}

Performa pertumbuhan tertinggi ikan tambakan terdapat pada padat tebar $25 \mathrm{ekor} / \mathrm{m}^{2}$.

\section{UCAPAN TERIMA KASIH}

Penulis mengucapkan terima kasih kepada Ir. Anang Hari Kristanto, M.Sc., Ph.D., Drs. Jojo Subagja, M.Si., Sdr. Deni Irawan, dan Sirodiana atas kontribusinya selama penelitian berlangsung. Penelitian ini merupakan bagian dari penelitian yang dibiayai oleh DIPA BPPBAT Tahun 2016.

\section{DAFTAR ACUAN}

Arifin, 0.Z., Subagja, J., Prakoso, V.A., \& Suhud, E.H. (2017a). Effect of stocking density on growth performance of domesticated barb (Barbonymus balleroides). Indonesian Aquaculture Journal, 12(1), 1-6.

Arifin, O.Z., Prakoso, V.A., \& Pantjara, B. (2017b). Ketahanan ikan tambakan (Helostoma temminkii) terhadap beberapa parameter kualitas air dalam lingkungan budidaya. Jurnal Riset Akuakultur, 12(3), 241-251.

Augusta, T.S. (2016). Upaya domestikasi ikan tambakan (Helostoma temminckii) yang tertangkap dari Sungai Sebangau. Jurnal IImu Hewani Tropika, 5(2), 82-87.

Cheah, H.S., Sharr, H.A., Ang, K.J., \& Kabir, A. (1985). An evaluation of the use of egg yolk, Artemia nauplii, microworms and moina as diets in larval rearing of Helostoma temmincki Cuvier and Valenciennes. Pertanika, 8(1), 43-51.

Effendie, M.I. (2002). Biologi perikanan. Yogyakarta: Yayasan Pustaka Nusantara, $163 \mathrm{hlm}$.

Gustiano, R., Kusmini, I.I., \& Ath-thar, M.H.F. (2015). Mengenal sumber daya genetik ikan spesifik lokal air tawar indonesia untuk pengembangan budidaya. Bogor: PT IPB Press, $51 \mathrm{hlm}$.

Hepher, B. \& Pruginin, Y. (1981). Commercial fish farming: with special reference to fish culture in Israel. John Wiley \& Sons Inc., p. 175-191.

Joko, Muslim, \& Ferdinan, H.T. (2013). Pendederan larva ikan tambakan (Helostoma temminckii) dengan padat tebar berbeda. Jurnal Perikanan dan Kelautan, 18(2), 59-67.

National Research Council. (1993). Nutrient requirements of fish. Washington, D.C.: National Academic of Science, $128 \mathrm{pp}$.

Rainboth, W.L. (1996). FAO species identification field guide for fishery purposes. Fishes of the Cambodian Mekong. Rome: FAO, 265 pp.

Randall, D. (1982). The control of respiration and circulation in fish during exercise and hypoxia. Journal of Experimental Biology, 100, 275-288.

Smith, K.J. \& Able, K.W. (2003). Dissolved oxygen dynamics in salt marsh pools and its potential impacts on fish assemblages. Marine Ecology Progress Series, 258, 223-232.

Weber, M. \& de Beaufort L.F. (1922). The fishes of the Indo-Australian Archipelago. IV. Heteromi, Solenichthyes, Synentognathi, Percesoces, Labyrinthici, Microcyprini. Brill, Leiden, 410 pp.

Yulianti, P., Kadarini, T., Rusmaedi, \& Subandiyah, S. (2003). Pengaruh padat penebaran terhadap pertumbuhan dan sintasan dederan ikan nila GIFT (Oreochromis niloticus) di kolam. Jurnal Iktiologi Indonesia, 3(2), 63-66. 